\title{
DIE OORSPRONG VAN AMPTELIKE TWEETALIGHEID
}

\section{IN SUID-AFRIKA}

Die jaar 1900. Op 13 Maart is Bloemfontein en op 5 Junie Pretoria deur die Engelse troepe beset. Daarmee het 'n einde gekom aan Hollands, die landstaal van die Republieke, as 'n amptelike taal in Suid-Afrika. Dis waar dat Hollands in Kaapland 'n sekere mate van amptelikheid besit het (praat in dic Parlement, vertaling van sekere regeringspublikasies, Dutch as opsionele eksamenvak in die onderwys, ens.), maar staatsregterlike gelykheid van Hollands met Engels is nooit wetlik vasgestel nie. Engels was die enigste offisiële landstaal. Ewenso in Natal, waar destyds omtrent glad geen konsessies aan IIollands toegestaan was nie. Deur die verowering van die Oranje-Vrystaat en clic Zuid-Afrikaansche Republiek het die Engelse taal die Suid-Afrikaanse kolonies, van die Kaap tot die Limpopo, in die landsregering volkome beheers. Die strewe van lord Charles Somerset en sy navolgers in die vorige eeu is in 1900 deur lord Milner bekroon.

En tog, slegs tien jaar na hierdie datum, het SuidAfrika by sy Uniewording offisieel 'n tweetalige land geword! Wat was daarvan die oorsaak? Hieroor is al baie geskryf en allerlei redes is genoem waarom dit natuurlikerwys so moes kom. Die vasberade houding van genl. Hertzog om Hollands gelyke regte met Engels te gee, of anders die beplande unifikasie van die vier Suid-Afrikaanse kolonies te laat misluk, word meestal wel as die vernaamste oorsaak genoem, maar die Vrystaat sou daarentë op die duur nie los van die Unie kon gebly het nie, ingeval die drie ander kolonies tot 'n eentalige (Engels) Unie sou besluit het. Die dreigement van genl. Hertzog was wel sterk, maar beslis nie effektief genoeg 
nie. Daar moes dus nog andere beweegredes, kragtiger selfs, gewees het.

Sommige skrywers beklemtoon die opmerklike konsiliasiegees wat by Engelse en Afrikaanse leiers in daardie dae geheers het, en lê veral die nadruk daarop dat die voorstel tot amptelike tweetaligheid juis van 'n onverdagte Britsgesinde afgevaardigde op die Nasionale Konvensie, nl. sir George Farrar, gekom het. Dit was sekerlik ' $n$ besonder vermeldenswaardige openbaring, veral as mens onbekend is met wat vooraf in verband hiermee agter die skerms plaasgevind het. Maar durf iemand daaruit aflei dat dic Engelssprekende verteenwoordigers daardeur almal oortuigde voorstanders van volstrekte tweetaligheid geword het? As dit so was, sou mos van 'n taalstryd in die volgende jare geen sprake gewees het nie!

Nee, daar is nog 'n ander oorsaak, moontlik van nog meer beslissende aard as bogenoemdes. En daaraan moet die naam van genl. Smuts verbind word, waarskynlik diz sterkste man agter die idee van Unievorming. Was hy so 'n gedugte bepleiter van die regte van Hollands, soos bv. genl. Hertzog was? Nee, niemand sal dit onderskryf nie - en tog, deur sy groot invloed is tweetaligheid ten slotte geaksepteer. Vanwaar dan is sy houding te verklaar? Om dit kortliks te stel: hy was gekompromitteer om daardie standpunt in te neem. Waardeur? Deur sy eie onderwyswetgewing in die destydse selfbesturende Transvaal-kolonie. In daardie wet het hy sekere regte aan Hollands as taal en as medium toegeken, al het hy nie so ver gegaan as genl. Hertzog 'n jaar later in die onderwyswet van die Oranjerivier-kolonie nie. Maar tog, wetlik is Hollands die eerste keer sedert die Britse verowering van Transvaal as ' $n$ amptelike taal in die skole toegelaat. Dit was in 1907.

En nou moet ons 'n paar jaar vroeër teruggaan om te begryp waarom genl. Smuts tot hierdie konsessie aan Hollands besluit het. Uit innerlike oortuiging was dit sekerlik nie, want dan sou hy volkome gelyke regte vir beide tale in sy onderwyswet geëis het en dit ook kon deurgevoer het in die posisie waarin hy toe as koloniale sekretaris was, met 'n volgsame meerderheid in die des- 
tydse Legislative Assembly of the Transvaal. Bowendien sou hy dan ook tot vandag toe bekend gewees het as die groot leier in die taalstryd van daardie dae en daarna. Maar sy naam ontbreek ten enemale in die ry van taalpatriotte. Daar was dus iets anders wat hom genoop het tot toegewing aan die druk van die volksdeel waartoe hy behoort het om regte aan Hollands by wet vas te lê. Wat was dit?

Was dit die aksie-program van die „Het Volk"-party, waarvan hy die groot krag agter genl. Botha was en wat regte vir Hollands as een van sy doeleindes gepropageer het? Sekerlik ja, maar dit nie net alleen nie, want die brandendste politieke kwessie van daardie tyd (1904-07) was nie die taalvraagstuk nie, maar die grootskaalse invoer van Chinese arbeiders vir die goudmyne van die Witwatersrand. Hierdie ding was dit waaroor Transvaal se gevestigde inwoners in beroering gekom het $\mathrm{cn}$ waardeur die „Het Volk"-party so 'n aanhang en ondersteuning, ook van Engelssprekende burgers, gekry het.

Maar die taalkwessie kan darem nie buite rekening gelaat word nie, want langsaan die partypolitieke oplewing so kort na die Vrede van Vereeniging het ook 'n volksbeweging ontstaan wat gelyke regte vir altwee tale in die land se skoolstelsel geëis het. Dit was die bekende C.N.O.-beweging vir Christelike en Nasionale onderwys. En die leiers van die „Het Volk"-party het daarin 'n magtige hulpmiddel gesien om hul politieke ambisies te verwesenlik. Vandaar dat die Boeregeneraals Botha, Smuts en Beyers ook 'n aktiewe rol in daardie beweging gespeel het. Te meer omdat ook die leiers van die drie Hollandse kerke hul gewig daarby ingegooi het, waardeur meer as 200 skole en skooltjies dwarsdeur Transvaal ontstaan en gegroei het. By die verslane bevolking was daardie eenvoudige onderwysinrigtings populêr, omdat hulle die ou tradisies van die tenonder gegane Republiek probeer bewaar het deur oorwegend Hollands as voertaal te gebruik, deur godsdiensonderrig te gee ooreenkomstig Afrikaanse gewoontes, deur klem te lê op vaderlandse geskiedenis, en veral deurdat die meeste onderwysers mense was wat reeds in die ou Republiek as sodanig 
gedien had, baie van hulle saam op kommando in die oorlogsjare gewees het en dus die volle vertroue van die Afrikaanse ouers geniet het, terwyl die Engelse goewermentskole hoofsaaklik onder leiding van ingevoerde Britse leerkragte gestaan het.

Die C.N.O.-beweging was inderdaad 'n organisasie wat skole gestig het in opposisie teen die beleidsrigting van die nuutgestigte Engelse Onderwysdepartement. Onderhandelings met die outoriteite om hierdie skole as private skole te erken en daardeur subsidievoorregte te verkry, het dan ook totaal misluk. Instandhouding van die C.N.O.-skole was alleen moontlik deur bydraes van (verarmde) ouers, van kerkkollektes en van simpatiseerders met hierdie saak uit Nederland. Veral moet hier bygevoeg word dat die betrokke onderwysers bereid was om teen die geringste vergoeding hulle werk vol te hou, nieteenstaande aanloklike voorwaardes by die goewermentskole.

Toe die eleksietyd vir selfbestuur in 1906/07 vir Transvaal aanbreek en orals politieke vergaderings gehou is, het die leiers van die „Het Volk"-party vanselfsprekend nie net die invoer van Chinese veroordeel nie, maar ook die onderwysvraagstuk met die daaraan verbonde taalkwessie op die voorgrond gestel. Genl. Smuts het op tallose vergaderings die belofte afgelê dat, as sy party die oorwinning behaal, hy sou sorg dat daar 'n onderwyswet tot stand kom wat die hele bevolking sou bevredig!

Die „Het Volk"-party het gewen en genl. Smuts het daarin geslaag om 'n onderwyswet deur die Transvaalse Parlement te laat aanneem - sonder verdeling. Weens sy noue verband met die C.N.O.-beweging kon hy natuurlik nie nalaat om in daardie wet bepaalde regte aan Hollands toe te ken nie, al was dit slegs as tweederangstaal. Die opregte C.N.O.-voorstanders was egter hiermee nie tevrede nie en het ook dadelik 'n aksie (onder meer) teen die taalbepalings begin, maar die breë publiek wou genl. Smuts nie affronteer nie en het in daardie wet 'n belangrike stap voorwaarts gesien, $\mathrm{nl}$. van geen regte vir Hollands tot gedeeltelike regte, of anders gesê: van 
amptelike eentaligheid (Engels) tot amptelike tweetaligheid in die onderwys.

Sonder die C.N.O.-beweging sou dit in 1907 nooit suier gekom het nic. Oor die algemeen was die konsiliasiegees in daardie dae so oorheersend dat desnoods $\mathrm{Hol}$ lands in dic slag sou kon gebly het as dan maar op ander punte die docl bereik sou kon word. Maar die sterk persoonlikheid van genl. Smuts het dit nie nodig geag om die C.N.O.-mense met hul taaleise totaal te ignoreer nie. Hy het die stembusoorwinning vir 'n groot deel aan hulle te danke gehad en het hulle daarom nie heeltemal in die steek gelaat nie, al moes hy gevoel het dat hy met die amptelike erkenning van Hollands 'n presedent geskep het wat groot gevolge sou kon hê vir die ander dele van Suid-Afrika. Transvaal was, clanksy genl. Smuts, nee, danksy die C.N.O.-beweging, die eerste gebied in Suid-Afrika, na die Anglo-Boereoorlog, waar Hollands as amptelike taal erken is, al was dit dan slegs in die skole. In 1908 het die Oranje-Vrystaat gevolg en Kaapland pas na Uniewording. Genl. Smuts het die ideale van die C.N.O.-beweging nimmer heelhartig onderskryf nie; vir hom was dit slegs 'n welkome middel tot bereiking van sy politieke ambisies. Nogtans was hy te intiem daarmee verbonde gewees om nie ten minste in 'n geringe mate aan dic ideale gehoor te gee nie toe hy as koloniale sekretaris en minister van onderwys daartoe die mag verkry het.

Unievorming was kort hierna reeds in die lug, en omdat hy in Transvaal A gesê had, kon hy nie anders as om ook B te sê toe in die Nasionale Konvensie-vergaderings die taalkwessie aan die orde gekom het. Daardie $B$ van 'n kragfiguur as genl. Smuts, tot ondersteuning van genl. Hertzog se opregte begeerte tot taalgelykheid, het die deurslag gegee tot volkome amptelike tweetaligheid in die Uniegrondwet van 1910.

Word dit tot vandag toc besef dat die C.N.O.-beweging van 1903-07 eintlik die grondoorsaak van die amptelike tweetaligheid van ons land is?

\section{Pretoria.}

A. K. Bot. 